\title{
The Behavior of Using Masks during the Coronavirus Disease 19 Pandemic in Malang Regency, Indonesia: Application of Theory of Planned Behavior and Social Support
}

\author{
Riza Fikriana ${ }^{1 *}$ (D) Al $^{\text {Afik }^{2} \text { (D) Mila Marinda }}{ }^{1}$ D \\ ${ }^{1}$ Department of Nursing, Sekolah Tinggi IImu Kesehatan Kepanjen, Malang, Indonesia; ${ }^{2}$ Department of Emergency Care, \\ Universitas Muhammadiyah Yogyakarta, Yogyakarta, Indonesia
}

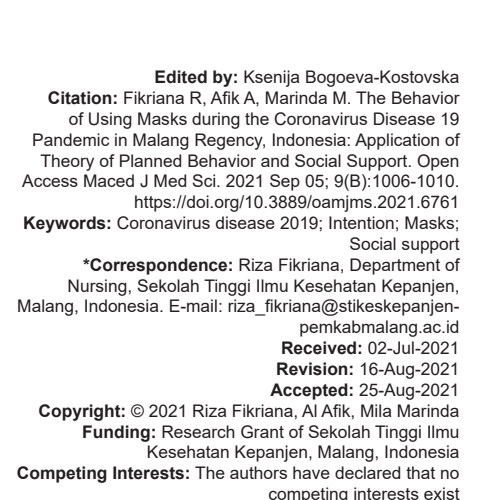

\begin{abstract}
BACKGROUND: The use of masks during the coronavirus disease 2019 (COVID-19) pandemic is one of the efforts to prevent its transmission. However, it was found that the behavior of the use of masks in the community is still low.

AIM: This study aims to analyze people's behavior in the use of masks with the theory of planned behavior and social support approach.

METHODS: Research using a cross-sectional design. The study was conducted on 90 people in Malang, Indonesia, taken with simple random sampling techniques. Variables measured are behavioral beliefs, evaluation of behaviora outcomes, normative beliefs, motivation to comply, control beliefs, perceived power, attitude, subjective norm, perceived control, intention, family support, peer support, and mask usage behavior. Research instrument is questionnaire. The data were analyzed using a linear regression test.

RESULTS: Results showed that the behavior of mask use according to the theory of planned behavior was significantly influenced by perceived power $(p<0.001)$, normative beliefs $(p=0.019)$, and intention to perform the behavior $(p=0.041)$. While in the social support component, peer support obtained a significant effect $(p=0.002)$.

CONCLUSION: As an effort to improve the behavior of the use of masks in the community during the COVID-19 pandemic, it is necessary to strengthen perceived power, normative beliefs, and intentions accompanied by good
\end{abstract} peer support so that the community complies with the use of masks for the prevention of transmission.

\section{Introduction}

Coronavirus disease 2019 (COVID-19) is a current global problem. The high spread of COVID19 occurs throughout the world results in increased worldwide burden [1], [2]. The number exposed to COVID-19 continues to increase daily around the world. As of August 5, 2020, the WHO reported 18,354,342 confirmed COVID-19 patients with 696,147 deaths [3]. The C-19 pandemic not only causes health problems for people exposed, such as acute respiratory diseases and resulting in death [4], [5], but this also impacts the surrounding environment where the COVID-19 pandemic increases psychosocial burden [6], [7], [8].

The WHO, as an organization that plays an important role in health issues in the world, provides recommendations to the public to be able to protect themselves from contracting COVID-19 [9]. The use of masks is one of the preventive efforts that must be made to reduce the spread of COVID-19 in addition to other preventive measures such as hand hygiene, physical distancing, etc. [10]. But study in Sulawesi Tenggara Indonesia shows that the use of masks in society is still very low. It is known that only $57.8 \%$ use masks when out of the house, $35.5 \%$ rarely use and $6.7 \%$ do not use masks [11]. These results illustrate that the level of public awareness in the use of masks as part of preventing the transmission of COVID-19 is still not maximized.

Health behavior is influenced by several factors. The previous studies have shown that a person's behavior during the COVID-19 pandemic is influenced by COVID-19 awareness, knowledge, and preparedness [12], [13], [14]. Other studies also support the results of this study where practices during the COVID-19 pandemic are significantly influenced by knowledge and attitudes [15]. Theory of planned of behavior explains that a person's behavior is initiated by the intention that forms it, where this intention is influenced by attitude, subjective norm, and perceived behavioral control [16]. Studies show behavioral intentions are strongly associated with perceived behavioral control, either directly or indirectly [17].

Social support is also one of the important components in influencing one's health status [18]. Studies show social support affects emotional response [19]. Social support is positively related to the search for health information for a person and has an indirect 
impact in influencing one's intention to conduct healthy living behaviors [20].

Several studies have been conducted related to the problem of COVID-19, but studies that analyze the behavior of mask use by referring to theory planned of behavior and social support have not been found. The purpose of this study is to analyze the behavior of mask use in theory-based society planned behavior and social support during the COVID-19 pandemic.

\section{Methods}

\section{Study design and setting}

Research uses a cross-sectional design. The population is a community in Boro Selatan Kepanjen, Malang regency Indonesia. The population of this research as many as 120 people. Sample criteria were aged $15-50$ years and willing to fill out the online form. If participant do not meet these criteria, participants are excluded from the sample. Sample was taken by a simple random sampling technique as many as 90 people sample recruitment in March 2021.

\section{Data collection}

Variables studied include independent variables such as behavioral beliefs, evaluation of behavioral outcomes, normative beliefs, motivation to comply, control beliefs, perceived power, attitude, subjective norm, perceived control, intention, family support, and peer support. Dependent variable is the behavior of the use of masks. Instrument is in the form of questionnaires taken from the Theory of Planned Behavior Questionnaire [21] and modified according to the needs of researchers. Questions listed in the TPB questionnaire consist of behavioral beliefs, evaluation of behavioral outcomes, normative beliefs, motivation to comply, control beliefs, perceived power, attitude, subjective norm, perceived control, and intention. The family and peer support questionnaires are taken from the researcher's modified social support questionnaire [22]. Data retrieval is done online by filling in the answer to the questions through Google Forms. The answer of each statement on each variable is measured using a Likert scale consisting of four answer options. Variable behavioral beliefs, evaluations of behavioral outcomes, attitude toward the behavior, subjective norm, perceived behavioral control using answer option are disagreeing, agreeing, and strongly agreeing. Variable normative beliefs, control beliefs, perceived power, intentions to perform the behavior, family support, peer support, and behavior using answer options are never (not once), sometimes (1-3 day/week), often (4-5 day/week), and always (everyday). Variable motivations to comply with the choice of answers from do not care (never pay attention), little care (little attention: 1-3 day/week), care (more attention: Almost everyday). and care deeply (full attention: Everyday).

\section{Statistical analysis}

The presentation of the respondent's characteristic data uses a frequency distribution. Meanwhile, each variable is calculated the mean and standard deviation. Data analysis to show a significant effect of independent and dependent variable is performed with linear regression tests using the SPSS for Windows 25 program.

\section{Results}

The characteristics of respondents in this study are people over the age of 17 years with the distribution of characteristics by Table 1 . Table 1 also displays the behavior of using masks.

Table 1: Respondent Characteristics and the Behavior of Using Masks

\begin{tabular}{lll}
\hline Respondent Characteristics & $\mathrm{n}$ (frequency) & Percentage \\
\hline Age (years) & 28 & 31 \\
$15-20$ & 40 & 44 \\
$21-30$ & 14 & 16 \\
$31-40$ & 8 & 9 \\
$41-50$ & 34 & 38 \\
Sex & 56 & 62 \\
$\quad$ Male & & \\
$\quad$ Female & 6 & 7 \\
Education & 14 & 56 \\
$\quad$ Elementary school & 50 & 22 \\
Junior high school & 20 & 44.4 \\
$\quad$ Senior high school & & 42.2 \\
$\quad$ College & 40 & 13.3 \\
The Behavior of Using Masks & 38 & \\
$\quad$ Good & 12 & \\
Enough & & \\
Less & & \\
\hline
\end{tabular}

Table 2 describes that behavioral belief has the highest mean value and control beliefs have the lowest value compared to other components of the theory of planned behavior approach. In the social support component, it is obtained that family support has the highest mean value compared to peer support.

Table 2: Theory of Planned Behavior and Social Support

\begin{tabular}{lll}
\hline Theory of Planned Behavior and Social Support & Mean & Deviation SD \\
\hline Behavioral belief & 3.354 & 0.594 \\
Evaluation of behavioral outcome & 3.299 & 0.565 \\
Normative beliefs & 2.950 & 0.811 \\
Motivation to comply & 3.333 & 0.734 \\
Control beliefs & 2.923 & 0.521 \\
Perceived power & 2.952 & 0.577 \\
Attitude toward the behavior & 3.291 & 0.623 \\
Subjective norm & 3.244 & 0.646 \\
Perceived behavioral control & 2.778 & 0.546 \\
Intention to perform the behavior & 3.178 & 0.773 \\
Family support & 3.118 & 0.622 \\
Peer support & 2.373 & 0.678 \\
\hline
\end{tabular}

Table 3 illustrates that peer support, perceived power, normative beliefs, and intention to perform the behavior have a significant effect on the behavior of mask use in the community during the COVID-19 pandemic. These results illustrate that high normative 
beliefs, strong perceived power, high intentions, and good peer support will improve the behavior of mask use in society.

Table 3: Interpretation of Linear Regression Test

\begin{tabular}{llllll}
\hline Model & $\mathrm{B}$ & $\mathrm{SE}$ & $\mathrm{B}$ & $\mathrm{T}$ & $\mathrm{p}$ \\
\hline (Constant) & 2.800 & 3.122 & & 0.897 & \\
Normative beliefs & 0.191 & 0.080 & 0.226 & 2.388 & 0.019 \\
Perceived power & 0.378 & 0.099 & 0.319 & 3.815 & 0.000 \\
Intention to perform the behavior & 0.195 & 0.094 & 0.220 & 2.071 & 0.041 \\
Peer support & 0.256 & 0.082 & 0.254 & 3.131 & 0.002 \\
\hline
\end{tabular}

\section{Discussion}

The use of masks is an important behavior to prevent the transmission of COVID-19. The results of the study illustrate that the behavior of using masks is good enough. This behavior is influenced by perceived power, peer support, normative beliefs, and intentions. Perceived power is the most influential component of mask usage behavior. Perceived power describes the effect a person feels on a condition that causes the behavior to be easy or difficult to carry out. This means that the perceived power possessed by a person becomes the main key to the formation of one's behavior. The internal strength felt toward the self and the environment becomes an important factor in behavior. This study is in line with other studies that result in perceived power encourages one's behavior in organizing [23]. Perceived good power will be able to improve good health behavior as well. Perceived power is bad where a person feels the condition in his environment becomes an obstacle to conduct health behavior, and then it also affects the behavior shown by a person.

The results of the study showed that peer support had a significant effect on the behavior of mask use in the community. This illustrates that peer support becomes an important component of the social environment for a person to influence how to behave. This result is in line with other studies, which obtained that peer support can improve one's self-care and quality of life [24]. Peer support provides benefits in efforts to prevent disease and risky behaviors [25], [26]. Peer support is the provision of a supportive environment from peer groups in the form of informational support, instrumental support as well as emotional support, and awards. The availability of such support can affect a person's behavior.

Normative beliefs are also found to have a significant effect on the behavior of mask use. These results illustrate that a person's beliefs regarding whether the existing reference to the behavior of the use of masks by a person is appropriate or inappropriate, making guidelines for him to take action on the importance of the use of masks for the prevention of transmission of COVID-19. The rules set out in the environment relate to the obligation to comply with health protocols where one is obliged to use a mask, making a person choose to comply with the rules by carrying out the behavior of the use of masks. Other studies show that normative beliefs become predictors that influence a person's behavior in choosing food [27]. Normative beliefs have a positive influence on social norms and attitudes, which will affect one's intentions in behaving [28].

The last construct of planned behavior has a significant effect on the behavior of the use of masks, namely, intention. A strong intention will improve compliance behavior toward the use of masks. The intention of a person to comply with the use of a mask indicates a perceived possibility to take action to use the mask to protect himself from contracting COVID-19. The intention is indirectly influenced by one's knowledge [29]. The intention is also influenced by self-efficacy, response-efficacy, and fear where it can be linked to a person's health behavior [30].

\section{Conclusion}

The behavior of the use of masks during the COVID-19 pandemic in the community to prevent the transmission of COVID-19 is influenced by perceived power, normative beliefs, peer support, and intention. Perceived good power, high normative belief, and strong intention from the community will have an impact on compliance in using masks. Besides, the presence of good peer support in providing informational, instrumental, and emotional support will have a positive impact on the use of masks. The practical implication of this study is that there needs to be sustainable health promotion efforts so that people have a high awareness of the use of masks through strengthening internal beliefs and providing good peer support.

\section{The Limitation of Study}

This study has not described the bias factors that can affect the behavior of using masks in the community. Further studies are needed to analyze these factors.

\section{Ethical Approval}

The research study was approved by the 
Health Research Ethics Committee of Sekolah Tinggi IImu Kesehatan Kepanjen, Malang, Indonesia.

\section{References}

1. Miller LE, Bhattacharyya R, Miller AL. Data regarding countryspecific variability in COVID-19 prevalence, incidence, and case fatality rate. Data Brief. 2020;32:106276. https://doi. org/10.1016/j.dib.2020.106276.

2. Mafruchati M. The use of dates against COVID-19, based on effectiveness or religion's believe? trends and relevance analysis in big data. Syst Rev Pharm. 2020;11(8):394-9.

3. World Health Organization. Coronavirus disease (COVID-19) Situation Report-198. Practice. 2020;14(6):e01218.

4. Rahmani AM, Mirmahaleh SY. Coronavirus disease (COVID19) prevention and treatment methods and effective parameters: A systematic literature review. Sustain Cities Soc. 2021;64:102568. https://doi.org/10.1016/j.scs.2020.102568 PMid:33110743

5. Nugraha D, Kloping NA, Yudhawati R, Purwandhono A, Hidayati HB. A current update in COVID-19 associated acute respiratory distress syndrome: Focus on mesenchymal stem cell therapy. Anaesthesia Pain Inten Care. 2020;24(6):671-81. https://doi. org/10.35975/apic.v24i6.1404

6. Megatsari $H$, Laksono $A D$, Ibad M, Herwanto $Y T$, Sarweni $K P$, Geno RA, et al. The community psychosocial burden during the COVID-19 pandemic in Indonesia. Heliyon. 2020;6(10):e05136. https://doi.org/10.1016/j.heliyon.2020.e05136

7. Nursalam N, Sukartini T, Priyantini D, Mafula D, Efendi F. Risk factors for psychological impact and social stigma among people facing COVID-19: A systematic review. Syst Rev Pharm. 2020;11(6):1022-8. https://doi.org/10.2196/24487

8. Pramukti I, Strong C, Sitthimongkol Y, Setiawan A, Pandin MG, Yen CF, et al. Anxiety and suicidal thoughts during the COVID-19 pandemic: Cross-country comparative study among Indonesian, Taiwanese, and Thai university students. J Med Internet Res. 2020;22(12):24487.

PMid:33296867

9. Giacalone A, Rocco G, Ruberti E. Physical health and psychosocial considerations during the COVID-19 outbreak. Psychosomatics. 2020;61(6):851-2. https://doi.org/10.1016/j. psym.2020.07.005

10. World Health Organization. Mask Use in the Context of COVID19. COVID-19 Infection prevention and control/WASH. Geneva: World Health Organization; 2020. p. 1-10.

11. Pratiwi AD. Gambaran penggunaan masker di masa pandemi COVID-19 pada Masyarakat di Kabupaten Muna. Lit Inst. 2020;5(2):52-7.

12. Nindrea RD, Sari NP, Harahap WA, Haryono SJ, Kusnanto $\mathrm{H}$, Dwiprahasto I, et al. Survey data of COVID-19 awareness, knowledge, preparedness and related behaviors among breast cancer patients in Indonesia. Data Br. 2020;32:106145. https:// doi.org/10.1016/j.dib.2020.106145

PMid:32835041

13. Fenitra RM, Praptapa A, Suyono E, Kusuma PD, Usman I. Factors influencing preventive intention behavior towards COVID-19 in Indonesia. J Behav Sci. 2021;16(1):14-27.

14. Mudatsir M, Fajar JK, Wulandari L, Soegiarto G, IImawan $M$, Purnamasari $Y$, et al. Predictors of COVID-19 severity: A systematic review and meta-analysis. F1000Res. 2020;9:26186.

\section{PMid:33163160}

15. Saefi M, Fauzi A, Kristiana E, Adi WC, Muchson M, Setiawan $\mathrm{ME}$, et al. Survey data of COVID-19-related knowledge, attitude, and practices among indonesian undergraduate students. Data Br. 2020;31:105855. https://doi.org/10.1016/j.dib.2020.105855 PMid:32607405

16. Neto IL, Matsunaga LH, Machado CC, Günther H, Hillesheim $\mathrm{D}$, Pimentel CE, et al. Psychological determinants of walking in a Brazilian sample: An application of the theory of planned behavior. Transp Res Part F Traf Psychol Behav. 2020;73:3918. https://doi.org/10.1016/j.trf.2020.07.002

17. Tai HL, Tsang SS, Chen TY, Wang YJ. Preliminary study on applying the theory of planned behavior to DM nephropatzy patients undertaking the integrated chronic kidney disease program-using a case from a medical center in Taiwan. Hong Kong J Nephrol. 2015;17(2):S9. https://doi.org/10.1016/j. hkjn.2015.08.032

18. Wu F, Sheng Y. Social support network, social support, selfefficacy, health-promoting behavior and healthy aging among older adults: A pathway analysis. Arch Gerontol Geriatr. 2019;85:103934. https://doi.org/10.1016/j.archger.2019.103934

19. Fikriana R, Afik A. Self-belief and social support factors on the emotional response of patients with hypertension. J Glob Pharma Technol. 2020;12(1):440-6.

20. McKinley CJ, Wright PJ. Informational social support and online health information seeking: Examining the association between factors contributing to healthy eating behavior. Comput Hum Behav. 2014;37:107-16. https://doi.org/10.1016/j. chb.2014.04.023

21. Ajzen I. Sample TPB Questionnaire. Massachusetts: University Massachusetts Amherst; 2019. p. 1-9.

22. Nursalam N. Metodologi Penelitian IImu Keperawatan Pendekatan Praktis. Jakarta: Salemba Medika; 2016.

23. Hartner-Tiefenthaler M. Supervisors' power to deal with employees' inner resignation: How perceived power of the organization and the supervisor relate to employees' voluntary and enforced work behavior. Eur Manag J. 2020;39(2):260-9. https://doi.org/10.1016/j.emj.2020.08.001

24. Ebrahimi $H$, Abbasi $A$, Bagheri $H$, Basirinezhad $M H$, Shakeri S, Mohammadpourhodki R. The role of peer support education model on the quality of life and self-care behaviors of patients with myocardial infarction. Patient Educ Couns. 2021;104(1):130-5. https://doi.org/10.1016/j.pec.2020.08.002

PMid:32826102

25. Goldstein KM, Zullig LL, Oddone EZ, Andrews SM, Grewe ME, Danus S, et al. Understanding women veterans' preferences for peer support interventions to promote heart healthy behaviors: A qualitative study. Prev Med Rep. 2018;10:353-8. https://doi. org/10.1016/j.pmedr.2018.04.016 PMid:29868391

26. Edianto E, Waluyo A, Yona S. Correlation of family acceptance and peer support group toward sexual behavior risk on MSM with HIVIAIDS in Medan, Indonesia. Enferm Clín. 2019;29(2):18993. https://doi.org/10.1016/j.enfcli.2019.04.052 PMid:31289009

27. Northrup AA, Smaldone A. Maternal attitudes, normative beliefs, and subjective norms of mothers of 2-and 3-year-old children. J Pediatr Health Care. 2017;31(3):262-74. https://doi. org/10.1016/j.pedhc.2016.08.012 PMid:27745978

28. Fang WT, $\mathrm{Ng} \mathrm{E}$, Wang CM, Hsu ML. Normative beliefs, attitudes, and social norms: People reduce waste as an index of social relationships when spending leisure time. Sustain. 2017;9(10):9101696. https://doi.org/10.3390/su9101696

29. Guerin RJ, Toland MD. An application of a modified theory of planned behavior model to investigate adolescents' job safety 
knowledge, norms, attitude and intention to enact workplace safety and health skills. J Safety Res. 2020;72:189-98. https:// doi.org/10.1016/j.jsr.2019.12.002

PMid:32199561

30. Brouwer-Goossensen D, van Genugten L, Lingsma H, Dippel D,
Koudstaal P, den Hertog H. Determinants of intention to change health-related behavior and actual change in patients with TIA or minor ischemic stroke. Patient Educ Couns. 2016;99(4):64450. https://doi.org/10.1016/j.pec.2015.10.028

PMid:26561311 